2019-05

\title{
Linear and Nonlinear Buckling Analysis of Castellated Beams
}

Kim, Boksun

http://hdl.handle.net/10026.1/14327

10.18178/ijscer.8.2.83-93

International Journal of Structural and Civil Engineering Research

EJournal Publishing

All content in PEARL is protected by copyright law. Author manuscripts are made available in accordance with publisher policies. Please cite only the published version using the details provided on the item record or document. In the absence of an open licence (e.g. Creative Commons), permissions for further reuse of content should be sought from the publisher or author. 
Published in

International Journal of Structural and Civil Engineering Research Vol. 8, No. 2, May 2019

doi: 10.18178/ijscer.8.2.83-93

Manuscript received December 11, 2018; revised March 11, 2019; Accepted March 18, 2019

\title{
Linear and Nonlinear Buckling Analysis of Castellated Beams
}

\author{
Sahar S. Elaiwi \\ University of Plymouth/School of Engineering, Plymouth, UK \\ Email: sahar.elaiwi@plymouth.ac.uk \\ Boksun. Kim and Long-Yuan. Li \\ University of Plymouth/School of Engineering, Plymouth, UK \\ Email: boksun.kim@plymouth.ac.uk, long-yuan.li@plymouth.ac.uk
}

\begin{abstract}
The aim of the present paper is to investigate the effect of web openings on the lateral-torsional buckling resistance of castellated beams by using both analytical and numerical methods. The analytical approach is developed based on the principle of minimum potential energy, meanwhile elastic and inelastic numerical solutions obtained using ANSYS software are for the validation of the analytical solutions. The investigations are carried out through the application of uniformly distributed transverse loading on top flange of a castellated beam with common boundary conditions. The developed analytical solutions is can be used for the design and practical use.
\end{abstract}

Index Terms - castellated beams, lateral-torsional buckling, potential energy, elastic, inelastic, numerical analysis

\section{INTRODUCTION}

In some cases, castellated beams may undergo a lateral-torsional buckling before they reach to their ultimate limit state. Recent evidence explains that due to applying transverse loads on the major axis of the castellated beam, the cross section of the beam is affected by compression and tension stress. The combinations of these effects are prone to produce an instability state called lateral-torsional buckling. Kerdal, and. Nethercot [1] indicated that the behaviour of castellated beams is similar to the plain beam but the properties of the cross section should be considered to evaluate the lateraltorsional buckling.

Numerous experimental, theoretical and numerical investigations have shown that some factors have an impact on castellated beam's vulnerability to lateraltorsion buckling (http://www.scirp.org/journal/ojce). The factors include: the distance between the lateral supports to the compression of the flanges; boundary conditions; loading type and position, section type; material properties; magnitude and distribution of the residual stresses and geometric imperfections Martins et al [2]. Two basic design philosophies have been adopted for

Manuscript received December 14, 2018; revised; accepted

Copyright credit, project number, corresponding author, etc. determining the lateral-torsional buckling resistance of Ibeam with web openings under bending loads. The first design philosophy indicates that for I-beam with web openings, the design check of lateral-torsional buckling is decreased to be a lateral flexural buckling check of the compressed T-section at web opening. According to Nseir et al [3], this philosophy is conservative because the tension effect of the flange and the stiffness of torsional of the full cross-section are completely ignored. Nethercot, and Kerdal [4] elicit the other design philosophy. They performed experiments on eight castellated beams and noticed that the lateral-torsional buckling resistance is not affected by the web openings of the beam. Hence the design philosophy of lateraltorsional buckling for I-beam without web openings could be used to the I-beam with web openings, taking into consideration that the properties of the crosssectional should be calculated at the center of the castellation. The design specifications such as BSEN1993-1-1:2005 [5]; BS5950-1:2000 [6]; Australian standards AS4100 [7] and American standard AISC [8] provide methods, which are derived, based on the above philosophies, can be used to determine the lateraltorsional buckling resistance for I-beams with web openings.

Additionally, the researcher presented numerous of studies to understood the lateral-torsional buckling behavours of castellated beams, Mohebkhah [9] developed a nonlinear finite element method for simulating inelastic castellated beams with various loading cases to examine lateral-torsional buckling. The work also discussed the influence of moment gradient on the lateral torsional buckling of castellated beams. The FEA results of inelastic castellated beams with different slenderness were compared with the results obtained according to the design specifications AISC-LRFD. Mohebkhah [9] reported that the design specifications AISC-LRFD is unsafe because the values of moment gradient factors for inelastic beams provided in AISC are bigger than those determined by nonlinear FEA method. Zirakian and Showkati [10] carried out an experimental investigation to examine lateral-distortional buckling mode and discussed the interaction between local 
buckling and lateral-torsional buckling. In their work, six tests were performed on simply supported castellated beams exposed to a concentrated load. They reported that the interaction of different buckling modes would lead to a distortion of the cross-section of the castellated beam due to lack of strength as assumed during lateral-torsional buckling. The experimental results were compared with the analytical results of the elastic and inelastic lateral buckling loads, which were obtained by applying the South well, modified, and Massey extrapolation techniques to gain more accurate predictions of the critical buckling loads. Showkati [11] suggested several empirical formulas to calculate the bending coefficient of unbraced castellated beams. The comparison was made between his results and published data by previous studies. The results show that the elastic-bending capacities of castellated beams, which are subjected to the uniform distributed loads on the top flange, are affected by the section properties. Kohnehpooshi and Showkati [12] carried out the numerical investigations using finite element method for the evaluation of the effective flexural and torsional stiffness's, shear and tension effects of castellated beams on the overall failure of the beams when subjected to pure bending. The finite element method was carried out using ANSYS software by using 3-D nonlinear Shell Elements (SHELL181). Sweedan [13] utilized ANSYS software for simulating the lateraltorsional buckling of simply supported circular web openings beams. This study applied different cases of loading on simply supported circular web openings beams which associated with wide variety of parameters such as cross-sectional dimensions, lengths of beams and arrangement of web openings to find critical moment values and the moment-gradient factor. According to numerical results, this study reported that the momentgradient factor is affected by the beam geometry and slenderness. In addition, a simplified approach was proposed to enable accurate determination of a moment modification factor KLB for the cellular beams Ellobody [14] utilized analytical and experimental methods to investigate the interaction of buckling modes in castellated beams. Nonlinear finite element method was utilized to simulate 96 models of the castellated beam by using ABAQUS software. The effects of various characteristics such as cross section dimensions and length of the beam on the failure mechanisms of the castellated beams were examined. It was reported that web distortional buckling occurs on castellated beam because of high strength, but lateral torsional buckling failure due to the normal strength of castellated beam. Nseir et al. [3] used both the experimental and numerical methods to examine the lateral-torsional buckling resistance of circular web opening beams. In addition, they suggested an analytical design method. Three tests were conducted to make a comparison between the experimental and numerical results. Their study used a wide variety of parametric factors, including crosssectional shape, bending moment distribution, the relative size of the openings, and yield stress. The design methods provided in the design specifications BS5950-1, 3.1,
4:1985 and 1988 are adopted by Pachpor et al. [15] to examine the behaviour of circular web opening beams to predict the lateral-torsional buckling resistance. Panedpojaman [16] made efforts to calculate the lateraltorsional buckling resistance of I-beams with web openings under a constant bending moment. Two methods, namely General Method and Specific Method, were used. In addition, the section properties for the calculation were adopted according to design principle of Nethercot and Kerdal [14]. Kim et al [17] presented an analytical study with focussing on the web shear effects on the lateral-torsional buckling of simply supported castellated beams liable to pure bending and/or a uniformly distributed load. They performed this study by using the classical principle of minimum potential energy. They also reported that to increase the accuracy of the critical moments' value and loads, the average torsional constant of the full and reduced sections should be considered in calculations, instead of simply taking the average of the critical moments or loads. Sonck and Belis [18] presented a nonlinear numerical study to examine the behaviour of the lateral-torsional buckling of doubly symmetric castellated beams subjected to a constant bending moment. For calculations, the study took into account the modified residual stresses and the crosssectional properties at the centre of the web opening. The calculations for lateral-torsional buckling were based on the design specification BSEN1993-1-1: 2005 [5]. The results of the numerical study have been compared with experimental results to assess the effects of geometric imperfections, elastic-plastic material behaviours, and residual stresses. Kwani and Wijaya [19] presented a paper to investigate the lateral-torsional buckling of castellated beams. AISC specifications have no equation to determine the critical moment for lateral-torsional buckling for design purposes of castellated beams. Therefore, they adopted the collapse analysis by using finite element method to modify the correction factor of AISC formula for determining the critical moment of the castellated beam.

The objectives of this research are to enhancing the knowledge of the effect of web openings on the lateraltorsional buckling of castellated beams subjected to uniformly distributed transverse, and to develop analytical expressions for the critical load of lateraltorsional buckling of castellated beams subjected to uniformly distributed transverse load and to examine the linear and nonlinear and inelastic behaviour of castellated beams subjected to uniformly distributed load and to validate the analytical expressions of the critical load of lateral-torsional buckling

\section{ANALYTICAL PHILOSOPHY OF LATERAL- TORSIONAL BICKLING OF CASTELLATED BEAM}

The condition of changing the beam from straight stability state to lateral deflection and twist state occurs at the critical loads. A calculation method of elastic critical loads of castellated beams when the beam has a lateraltorsional buckling is presented in this chapter. The 
method is derived based on the principle of the total potential energy.

According to the model illustrated in, Fig. 1(a) the beam shear centre will have lateral and transverse displacements, respectively $v(x), w(x)$. Furthermore, the cross-section has an angle of twist $\phi(x)$. In the linear situation, the strain energy stored in the beam involves two parts; the energy caused by the deflection and the energy caused by the twist, which can be written as follows:

(a)

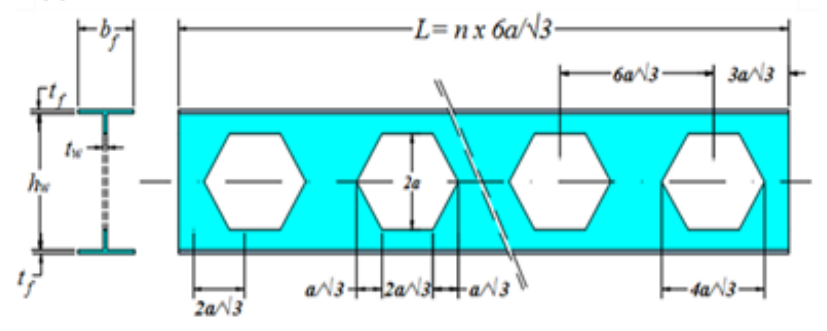

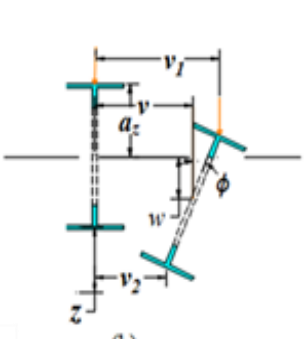

(b)

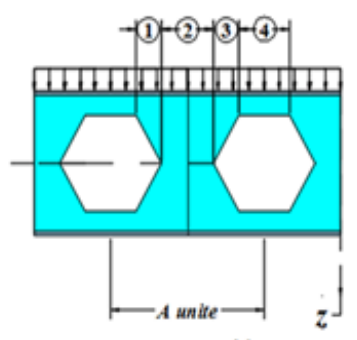

(c)

Figure 1. (a) Notations used in castellated beams. (b) Loading and displacements of web and displacement of flanges when lateraltorsional buckling occurred (c) Section properties of middle-part of web in four different regions. $I_{y 3}=I_{y 3}^{*}, I_{z 3}=I_{z 3}^{*}, J_{3}=J_{3}^{*}$ in region 2 , in region $4, I_{y 3}=I_{z 3}=J_{3}=0$, section properties vary with $\mathrm{x}$ in regions 1 and 3 .

$$
\begin{gathered}
U_{s}=\frac{1}{2} \int_{0}^{l}\left[E I_{y}\left(\frac{d^{2} w}{d x^{2}}\right)^{2}+E I_{z}\left(\frac{d^{2} v}{d x^{2}}\right)^{2}+\right. \\
\left.E I_{w}\left(\frac{d^{2} \phi}{d x^{2}}\right)^{2}+G J\left(\frac{d \phi}{d x^{2}}\right)^{2}\right] d x \\
U_{s}=\frac{1}{2} \int_{0}^{l}\left[E I_{y 1}\left(\frac{d^{2} w_{1}}{d x^{2}}\right)^{2}+E I_{z 1}\left(\frac{d^{2} v_{1}}{d x^{2}}\right)^{2}+G J_{1}\left(\frac{d \phi}{d x^{2}}\right)^{2}\right] d x \\
\quad+\frac{1}{2} \int_{0}^{l}\left[E I_{y 2}\left(\frac{d^{2} w_{2}}{d x^{2}}\right)^{2}+E I_{z 2}\left(\frac{d^{2} v_{2}}{d x^{2}}\right)^{2}+G J_{2}\left(\frac{d \phi}{d x^{2}}\right)^{2}\right] d x \\
+\frac{1}{2} \int_{0}^{l}\left[E I_{y 3}\left(\frac{d^{2} w_{3}}{d x^{2}}\right)^{2}+E I_{z 3}\left(\frac{d^{2} v_{3}}{d x^{2}}\right)^{2}+G J_{3}\left(\frac{d \phi}{d x^{2}}\right)^{2}\right] d x
\end{gathered}
$$

where $I_{y 1}=I_{y 2}$ and $I_{z 1}=I_{z 2}$ are the second moments of the T- sectional area about the $\mathrm{y}$ and $\mathrm{z}$ axes. $J_{1}=J_{2}$ is the torsional constant of the tee-section, $I_{y 3}$ and $I_{z 3}$ are the second moments of the cross-sectional area of the mid-part of the web about the $\mathrm{y}$ and $\mathrm{z}$ axes respectively, and $J_{3}$ is the torsional constant of the mid-part of the web. where $U_{s}$ is the strain energy, $l$ is the beam length, $E$ is the Young's modulus, $\mathrm{G}$ is the shear modulus and $\mathrm{J}$ is the torsional constant; $I_{y}$ and $I_{z}$ are the second moments of the cross-sectional area about the $y$ and $z$ axes respectively, $I_{w}$ is the warping constant. Because of web openings $I_{y}, I_{z}, I_{w}$ and $\mathrm{J}$ are introduced as a function of $x$.

In order to consider the web shear influence to determine the elastic critical lateral-torsional buckling loads in castellated beams, it is assumed that the crosssection of the castellated beam is decomposed into three parts, two of which represent the top T-section and bottom T-section, one of which represents the middlepart of the web. The analysis model for this study is illustrated in Fig. 1(a). The second assumption is that the displacements at the shear centres of the top and bottom tee-sections are small. The third assumption is that the warping constants of the top and bottom T-sections and the mid-part of the web are so small and therefore can be ignored. The displacements of the three parts in the castellated beam can thus be expressed as follows (see Fig. 1(b)) [17]:

$$
\begin{gathered}
v_{1}=v+\frac{h}{2} \sin \phi \approx v+\frac{h \phi}{2} \\
v_{2}=v+\frac{h}{2} \sin \phi \approx v+\frac{h \phi}{2} \\
w_{1}=w+\frac{h}{2}(1-\cos \phi) \approx w \\
w_{2}=w+\frac{h}{2}(1-\cos \phi) \approx w
\end{gathered}
$$

where $v_{1}$ and $v_{2}$ are the lateral displacements of the $\mathrm{s}$ hear centre of the top and bottom T-section, $w_{1}$ and $w_{2}$ ar e the transverse displacements of the shear centre of the $t$ op and bottom T-section, $(h)$ is the distance between the $\mathrm{s}$ hear centres of top and bottom T-sections. Hence, the stra in energy of the castellated beam based on the three parts
Hence, the formula of the strain energy of castellated beam (top T- section, bottom T- section and mid-part of the web), which is susceptible to deflection and twist due to uniformly distributed load at the top T- section, can be obtained by substituting (2)- (5) into (6) 


$$
\begin{gathered}
U_{s}=\frac{1}{2} \int_{0}^{l}\left[2 E I_{y 1}\left(\frac{d^{2} w_{1}}{d x^{2}}\right)^{2}+2 E I_{z 1}\left(\frac{d^{2} v_{1}}{d x^{2}}\right)^{2}+\frac{h^{2}}{2} E I_{z 1}\left(\frac{d^{2} \phi}{d x^{2}}\right)^{2}+2 G J_{1}\left(\frac{d \phi}{d x^{2}}\right)^{2}\right] d x \\
+\frac{1}{2} \int_{0}^{l}\left[E I_{y 3}\left(\frac{d^{2} w_{2}}{d x^{2}}\right)^{2}+E I_{z 3}\left(\frac{d^{2} v_{2}}{d x^{2}}\right)^{2}+G J_{3}\left(\frac{d \phi}{d x^{2}}\right)^{2}\right] d x
\end{gathered}
$$

According to Fig. 1(c), $I_{y 1}, I_{z 1}$ and $J_{1}$ are constants, while $I_{y_{3}}, I_{z 3}$ and $\mathrm{J}_{3}$ are depending upon the location of the web openings, therefore they are function of $x$. Hence, from the comparison between (7) and (1), it can be obtained, that:

$$
\begin{gathered}
I_{y}=2 I_{y 1}+I_{y 3} \\
I_{z}=2 I_{z 1}+I_{z 3} \\
I_{w}=\left(\frac{h}{2}\right)^{2} I_{z} \approx \frac{h^{2}}{2} I_{z 1} . \\
J=2 J_{1}+J_{3} .
\end{gathered}
$$

Note from (10) the warping strain energy cannot be ignored because the displacement compatibility occurs when the two T-sections assemble.
The potential energy, which is the negative value resulting from the applied loads when the lateral torsional buckling occurs, can be written as follows:

$$
\begin{aligned}
& W=-\int_{0}^{l}\left[M_{y}\left(\frac{d^{2} w}{d x^{2}}\right)+M_{y} \phi\left(\frac{d^{2} v}{d x^{2}}\right)+\right. \\
& \left.\frac{a_{z} q_{z}}{2} \phi^{2}\right] d x
\end{aligned}
$$

where $a_{z}$ refers to the $\mathrm{z}$-coordinate of the loading point, which is the vertical distance between the loading point and the shear centre of the beam, in this case, $a_{z}=$ $\frac{h_{w}}{2}+t_{f}$ because the uniformly distributed load is applied on the top flange of the beam.

In summary, by using (7) and (12), the equation of the total potential energy of the castellated beam considering lateral torsional buckling deflection can be expressed as follows:

$$
\begin{aligned}
\Pi=\frac{1}{2} \int_{0}^{l}[2 E & \left.I_{y 1}\left(\frac{d^{2} w_{1}}{d x^{2}}\right)^{2}+2 E I_{z 1}\left(\frac{d^{2} v_{1}}{d x^{2}}\right)^{2}+\frac{h^{2}}{2} E I_{z 1}\left(\frac{d^{2} \phi}{d x^{2}}\right)^{2}+2 G J_{1}\left(\frac{d \phi}{d x^{2}}\right)^{2}\right] d x \\
& +\frac{1}{2} \int_{0}^{l}\left[E I_{y 3}\left(\frac{d^{2} w_{2}}{d x^{2}}\right)^{2}+E I_{z 3}\left(\frac{d^{2} v_{2}}{d x^{2}}\right)^{2}+G J_{3}\left(\frac{d \phi}{d x^{2}}\right)^{2}\right] d x \\
& -\int_{0}^{l}\left[M_{y}\left(\frac{d^{2} w}{d x^{2}}\right)+M_{y} \phi\left(\frac{d^{2} v}{d x^{2}}\right)+\frac{a_{z} q_{z}}{2} \phi^{2}\right] d x
\end{aligned}
$$

For assumed displacement functions of $v(x), w(x)$.and $\phi(\mathrm{x})$.one can calculate the critical moment $\mathrm{M}_{\mathrm{cr}}$ from (13).
For a simply supported castellated beam under a uniformly distributed load applied on the top flange the critical moment was provided by [17] as follows:

$$
\begin{aligned}
\left(\frac{q_{z} l^{2}}{8}\right)_{c r}=\frac{-\left(\frac{h_{w}}{2}+t_{f}\right)+\sqrt{\left(\frac{h_{w}}{2}+t_{f}\right)^{2}+\left(\frac{\pi^{2}}{6}+\frac{1}{2}\right)^{2}\left[I_{w}+\frac{G\left(2 J_{1}+k J_{3}^{*}\right) l^{2}}{\pi^{2} E}\right] \frac{1}{\left(2 I_{z 1}+k I_{z 3}^{*}\right)}}}{\left(\frac{1}{3}+\frac{1}{\pi^{2}}\right)^{2}} \\
\times \frac{E\left(2 I_{z 1}+k I_{z 3}^{*}\right)}{l^{2}}
\end{aligned}
$$

when $I_{z 3}^{*}$ is negligible because $I_{z 3}^{*}<<2 I_{z 1}$. Thus, (14) can be simplified as: [17]:

$$
\left(\frac{q_{z} l^{2}}{8}\right)_{c r}=\frac{-\left(\frac{h_{w}}{2}+t_{f}\right)+\sqrt{\left(\frac{h_{w}}{2}+t_{f}\right)^{2}+\left(\frac{\pi^{2}}{6}+\frac{1}{2}\right)^{2}\left[\frac{I_{w}}{2 I_{z 1}}+\frac{G\left(2 J_{1}+k J_{3}^{*}\right) l^{2}}{2 I_{z 1} \pi^{2} E}\right]}}{\left(\frac{1}{3}+\frac{1}{\pi^{2}}\right)^{2}} \times \frac{2 I_{z 1} E}{l^{2}}
$$

For a pinned-fixed castellated beam the displacement functions of $v(x), w(x)$.and $\phi(x)$.can be assumed as follows:

$$
\begin{aligned}
& w(x)=A \sin \left(\frac{k \pi(l-x)}{l}\right) \sin \left(\frac{\pi(l-x)}{2 l}\right) \\
& v(x)=B \sin \left(\frac{k \pi(l-x)}{l}\right) \sin \left(\frac{\pi(l-x)}{2 l}\right)
\end{aligned}
$$




$$
\phi(x)=C \sin \left(\frac{k \pi(l-x)}{l}\right) \sin \left(\frac{\pi(l-x)}{2 l}\right)
$$

where $\mathrm{A}, \mathrm{B}$, and $\mathrm{C}$ are the constants to be determined. It is obvious that the above displacements functions satisfy the boundary conditions, that are $w=v=\phi=$

$$
U_{s}=\frac{41}{128} \frac{\pi^{4}}{l^{3}}\left[E\left(2 I_{y 1}+k I_{y 3}^{*}\right) A^{2}+E\left(2 I_{z 1}+k I_{z 3}^{*}\right) B^{2}+E I_{w} C^{2}+\frac{16}{41}\left(1+\frac{1}{\pi^{2}}\right) G\left(2 J_{1}+k J_{3}^{*}\right)\left(\frac{l}{\pi}\right)^{2} C^{2}\right]
$$

According to Kim. et al. [17] k refers to the fraction of the volume of the solid and holes in the mid-part of the web beam. For most castellated beams, the solid areas and holes in the mid-part of the web have equal area and thus leads to the value of $\mathrm{k}=0.5$.

The internal bending moment for a pinned-fixed castellated beam subject to a uniformly distributed load can be written as follows:

$$
\begin{gathered}
M_{y}(x)=\frac{3}{8} q_{z} l x-\frac{1}{2} q_{z} x^{2} \\
\prod=\frac{41}{128} \frac{\pi^{4}}{l^{3}}\left[E\left(2 I_{y 1}+k I_{y 3}^{*}\right) A^{2}+E\left(2 I_{z 1}+k I_{z 3}^{*}\right) B^{2}+\right. \\
+\frac{4 l q_{z}}{3 \pi} A+\frac{q_{z} \pi^{2} l}{20}\left(\frac{1}{3}+\frac{1}{\pi^{2}}\right) B C-\frac{a_{z} l}{8} \\
\text { The variation of }(22) \text { with respect to } A, B \text { and } C \\
\text { results in the following three algebraic equations: } \\
\frac{41 l}{128}\left(\frac{\pi}{l}\right)^{4}\left[2 E\left(2 I_{y 1}+k I_{y 3}^{*}\right) A\right]+\frac{4 l q_{z}}{3 \pi}=0 \\
\frac{41 l}{128}\left(\frac{\pi}{l}\right)^{4}\left[2 E\left(2 I_{z 1}+k I_{z 3}^{*}\right) B\right] \\
=-\frac{q_{z} \pi^{2} l}{20}\left(\frac{1}{3}+\frac{1}{\pi^{2}}\right) C
\end{gathered}
$$$$
\prod=\frac{41}{128} \frac{\pi^{4}}{l^{3}}\left[E\left(2 I_{y 1}+k I_{y 3}^{*}\right) A^{2}+E\left(2 I_{z 1}+k I_{z 3}^{*}\right) B^{2}+E I_{w} C^{2}+\frac{16}{41}\left(1+\frac{1}{\pi^{2}}\right) G\left(2 J_{1}+k J_{3}^{*}\right)\left(\frac{l}{\pi}\right)^{2} C^{2}\right]
$$$$
+\frac{4 l q_{z}}{3 \pi} A+\frac{q_{z} \pi^{2} l}{20}\left(\frac{1}{3}+\frac{1}{\pi^{2}}\right) B C-\frac{a_{z} l q_{z}}{8} C^{2}
$$

Substituting (20) into (12) yields an expression for the potential energy of the external loads as:

$$
W=\frac{4 l q_{z}}{3 \pi} A+\frac{q_{z} \pi^{2} l}{20}\left(\frac{1}{3}+\frac{1}{\pi^{2}}\right) B C-\frac{a_{z} l q_{z}}{8} C^{2}
$$

Combining (19) and (21) yields an expression for the total potential energy:

(26) leads to $A=0$

$$
\begin{aligned}
{\left[\frac{8 q_{z} l^{2}}{20}\left(\frac{1}{3}+\frac{1}{\pi^{2}}\right)\right]^{2}+\frac{41 a_{z} l^{2} q_{z}}{4 \pi^{2}} } & \left(E\left(2 I_{z 1}+k I_{z 3}^{*}\right)\left(\frac{\pi}{l}\right)^{2}\right) \\
= & {\left[\left(\frac{\pi}{l}\right)^{2}\left(\frac{41}{8}\right)^{2} E I_{w}+G\left(2 J_{1}+k J_{3}^{*}\right)\right]\left(E\left(2 I_{z 1}+k I_{z 3}^{*}\right)\left(\frac{\pi}{l}\right)^{2}\right) }
\end{aligned}
$$

Solving for $q_{z}$ from (27), it yields:

$$
\begin{aligned}
&\left(\frac{\mathrm{q}_{\mathrm{z}} \mathrm{l}^{2}}{8}\right)_{\mathrm{cr}}= \frac{-\left(\frac{\mathrm{h}_{\mathrm{w}}}{2}+\mathrm{t}_{\mathrm{f}}\right)+\sqrt{\left(\frac{\mathrm{h}_{\mathrm{w}}}{2}+\mathrm{t}_{\mathrm{f}}\right)^{2}+\frac{64 \pi^{2}}{20}\left(\frac{1}{\pi^{2}}+\frac{1}{3}\right)^{2}\left[\frac{\mathrm{I}_{\mathrm{w}}}{64}+\frac{\mathrm{G}\left(2 \mathrm{~J}_{1}+\mathrm{kJ} \mathrm{J}_{3}^{*}\right) \mathrm{l}^{2}}{41^{2} \pi^{2} \mathrm{E}}\right] \frac{1}{\left(2 \mathrm{I}_{\mathrm{z} 1}+\mathrm{kI}_{\mathrm{z} 3}^{*}\right)}}}{\frac{64 \pi^{2}}{20}\left(\frac{1}{\pi^{2}}+\frac{1}{3}\right)^{2}} \\
& \times \frac{41 \mathrm{E}\left(2 \mathrm{I}_{\mathrm{z} 1}+\mathrm{kI}_{\mathrm{z} 3}^{*}\right)}{\mathrm{l}^{2}}
\end{aligned}
$$

Again, if $I_{z 3}^{*}$ is neglected, (28) can be simplified as follows: [17]: 


$$
\begin{aligned}
& \left(\frac{q_{z} l^{2}}{8}\right)_{c r}=\frac{-\left(\frac{h_{w}}{2}+t_{f}\right)+\sqrt{\left(\frac{h_{w}}{2}+t_{f}\right)^{2}+\frac{64 \pi^{2}}{20}\left(\frac{1}{\pi^{2}}+\frac{1}{3}\right)^{2}\left[\frac{I_{w}}{64}+\frac{G\left(2 J_{1}+k J_{3}^{*}\right) l^{2}}{41^{2} \pi^{2} E}\right] \frac{1}{\left(2 I_{z 1}\right)}}}{\frac{64 \pi^{2}}{20}\left(\frac{1}{\pi^{2}}+\frac{1}{3}\right)^{2}} \\
& \times \frac{41 E\left(2 I_{z 1}\right)}{l^{2}}
\end{aligned}
$$

\section{NUMERICAL ANALYSIS}

The numerical computations are adopted using the ANSYS Programming Design Language (APDL) [20]. The modelling of castellated beams is carried out by 3D linear Quadratic 4-Node Thick Shell Element (SHELL181). This element presents four nodes with six DOF per node, i.e., translations and rotations on the X, Y, and $\mathrm{Z}$ axis, respectively. Maximum element size used in FEA is $5 \mathrm{~mm}$ for short length beams and $10 \mathrm{~mm}$ for long length beams. Elastic material model is used for linear analysis and elastic-perfectly plastic material model is used for nonlinear analysis with Young's modulus $\mathrm{E}=$ $2.1 \times 10^{5} \mathrm{MPa}$, Poisson's ratio $v=0.3$ and yield stress $\sigma_{\mathrm{y}}=275 \mathrm{MPa}$. In the nonlinear analysis geometrical nonlinearity is also considered. The transverse load is applied as a line load on the junction between the top flange and web. In the present study the equations of nonlinear equilibrium are solved by using the procedure of the Newton-Raphson method, in conjunction with Arc-Length Method. Simply or fixed boundary conditions are applied to all nodes on the end section to vertical displacement only. Lateral displacement is restrained to all nodes on both end sections. Axial displacement is applied only at one node at one end section to avoid rigid displacement

\section{SERVICEABLITY LIMIT STATE}

Structural serviceability indicates the limit states that are considered in the design of the structure. Therefore, to ensure that a building is safe, these conditions should be followed. The current standard serviceability design has different deflection limits which depend on the purpose of service as it is intended, and the material of the structure. The aim of this section is to validate the results of deflection that are calculated from the analytical linear method, linear, and nonlinear finite element methods. In this study, the value of deflection under the serviceability load that was considered is $l / 250$ because the structure is steel.

\section{DISCISSION}

Comparisons of critical moments of lateral torsional buckling of castellated beams are presented in Fig. 2 and Fig. 3 for simply supported beams and Fig. 5 and Fig. 6 for pinned-fixed beams. This comparison involves the results of linear analytical solutions, linear buckling 3D finite element analysis using ANSYS, and nonlinear 3D finite element analysis (geometrical nonlinear and material inelasticity) using ANSYS software for various length beams with different flange widths, in which the value of linear critical lateral torsion buckling moment $\left(\mathrm{M}_{\mathrm{cr}}\right)$ was obtained by (15) for simply support beams and pinned-fixed beams by (29). Moreover, the yield moment is obtained by $\mathrm{M}_{\text {yield }}=\frac{2 \sigma_{y} I_{\text {reduced }}}{h_{w}+2 t_{f}}, \quad\left(\sigma_{y}=\right.$ $275 \frac{\mathrm{N}}{\mathrm{mm}^{2}}, \quad \mathrm{I}_{\text {reduced }}=\frac{b_{f}\left(h_{w}+2 t_{f}\right)^{3}}{12}-\frac{(2 a)^{3} t_{w}}{12}-$ $\left.\frac{\left(h_{w}\right)^{3}\left(b_{f}-t_{w}\right)}{12}\right)$

From these figures, it can be seen that in each group of flange width, the curves of the analytical solution and numerical analysis results of both linear and nonlinear analysis have a similar variation pattern. However, it is observed from these figures that in the case of nonlinear analysis of castellated beams, the critical lateral torsion buckling load $\left(\mathrm{M}_{\mathrm{cr}} / \mathrm{M}_{\text {yield }}\right)$ drops with the increase the flange width and the decrease of beam length. The previous studies mentioned that the reasons for this are because lateral torsional buckling load of castellated beam is influenced by the lateral flexural and warping rigidities Mohebkhah [21]. In this study, the increasing flange width leads firstly to increase lateral flexural and warping rigidities, and secondly to increase applying moments on castellated beams. These issues indicate that the geometrical nonlinear and material inelasticity lateral torsional buckling resistance of castellated beams with short beam length is limited to the ultimate load carrying capacity, in which no lateral torsional buckling occurs. In addition, the web opening under high loads makes the castellated beam more prone to compression buckling of web; and failure can occur in local loading areas or reaction force region (Kerdal and Nethercot [1] and Ellobody [14]

Fig. 4 for simply supported beams, Fig. 7 for pinned fixed beams show a comparison of the load-deflection curves of pinned-fixed castellated beams. The comparison involves the results of nonlinear 3D finite element analysis using ANSYS software, and deflection limit $(1 / 250)$ for different beam lengths with different flange widths. The load is presented as the increments of load calculated following by $\mathrm{q}_{\max }=16 \frac{\sigma_{\mathrm{y}} \mathrm{I}_{\text {reduced }}}{1^{2}\left(\mathrm{~h}_{\mathrm{w}}+2 \mathrm{t}_{\mathrm{f}}\right)}$. The latter reflects that the critical lateral torsional buckling for short beam length with wide flange is influenced by geometry, web openings, boundary conditions, and material properties of the beam. As a result, the designer should consider a nonlinear analysis for short castellated beams with wide flange for design calculations.

Fig. 8 is shown that the failure mode of short castellated beams is dominated by the plastic failure, whereas the failure mode of long castellated beams is dominated by the lateral-torsional buckling failure mode, which was obtained from the numerical analysis for the 
beam of length $(l=3.5 \mathrm{~m})$ with wide flange width $(b f=$ $200 \mathrm{~mm}$ and $b f=250 \mathrm{~mm})$.

\section{CONCLUSIONS}

This study has been carried out to investigate the behaviour of simply support and simply-fixed castellated beams subjected to uniformly distributed load using analytical and numerical solution. Comparison has been made between the results of the linear analysis and the geometrical and material nonlinear analysis by using finite element method. The main conclusions can be summarized as follows:

- The critical load of lateral-torsional buckling of castellated beams is influenced by the beam size, web openings, boundary conditions, and material properties of the beam.

- The value of torsional constant should be calculated by using the average torsional constant of the full and reduced section properties.

- The failure mode of short castellated beams is dominated by the plastic failure, whereas the failure mode of long castellated beams is dominated by the lateral-torsional buckling failure mode.

- The longer the beam, the closer the critical load obtained from the linear lateral-torsional buckling analysis to the failure load obtained from of the full nonlinear analysis.

- When the serviceability is also considered, the deflection limit seems to be the dominant criterion in controlling the load in most of the beam length regions

- The longer the beam, the less importance of the nonlinearity need to be considered.

\section{CKNOWLEDGMENT}

The first author is grateful to the Ministry of Higher Education and Scientific Research in Iraq to the financial support of her PhD study at the University of Plymouth.

\section{REFERENCES}

[1]. D. Kerdal, and D. Nethercot, "Failure modes for castellated beams," Journal of Constructional Steel Research, vol. 4, no. 5, pp. 295-315, 1984.

[2]. C.H. Martins, F.P.V. Fer- reira, A. Rossi, and E.V.W. Trentin, "Numerical Analysis of Physical and Geometrical Imperfections in Cellular Beams," Open Journal of Civil Engineering, vol. 7, pp. 116- 129, 2017

[3]. J. Nseir, M. Lo, D. Sonck, H. Somja, O. Vassart, and N. Boissonnade, "Lateral torsional buckling of cellular steel beams," in Proc. SSRC2012. The structural stability research council annual stability conference Grapevine, Texas, 18 Apr, 2012.

[4]. D. Nethercot, and D. Kerdal, "Lateral-torsional Buckling of Castellated Beams", The Structural Engineer, vol. 60B, 3, pp. 5361, 1982.

[5]. British Standard Institution. Design of steel structures, Part 1.1: General rules and rules for buildings, Eurocode 3, BSENV 1993$1-1,2005$.

[6]. British Standard Institution. Structural use of steelwork in building, Part 1: code of practice for design rolled and welded sections, BS 5950-1, 2000.

[7]. Australian standards AS4100 Standards Australia (SA), AS 4100 Steel Structures Sydney, Australia, 1998.
[8]. American Institute of Steel Construction (AISC). ANSI/AISC 360-10 specification for structural buildings14th ed, Chicago, Illinois, USA, 2011

[9]. A. Mohebkhah, "The moment-gradient factor in lateral-torsional buckling on inelastic castellated beams," Journal of Constructional Steel Research, vol. 60, no.10, pp. 1481-1494, (2004).

[10]. T. Zirakian, and H. Showkati, "Distortional buckling of castellated beams," Journal of Constructional Steel Research, vol. 62, no.9, pp. 863-871, 2006.

[11]. H. Showkati, "Lateral-Torsional Buckling of Castellated Beams," Iranian Journal of Science \& Technology, Transaction B, Engineering, vol. 32, pp. 153-156, 2008.

[12]. O. Kohnehpooshi, and H. Showkati, "Numerical Modeling and Structural Behavior of Elastic Castellated Section," European Journal of Scientific Research, vol. 31, no. 2, pp. 306-18, 2009.

[13]. A. Sweedan, "Elastic lateral stability of I-shaped cellular steel beams," Journal of Constructional Steel Research, vol. 67, no, 2, pp. 151-163, 2011.

[14]. E. Ellobody, "Interaction of buckling modes in castellated steel beams," Journal of Constructional Steel Research, 67(5) (2011) 814-825.

[15]. P.D. Pachpor, L.M. Gupta, and N.V. Deshpande, "Analysis and design of cellular beam and its verification," International Conference on Applied Computing, Computer Science and Computer Engineering, IERI Procardia,vol. 7 pp. 120-127, 2014.

[16]. P. Panedpojaman, "Investigation on lateral torsional buckling resistance of ec3 for cellular beam," International Journal of Advances in Mechanical and Civil Engineering, vol. 2, no. 4, pp. 389-399, 2015.

[17]. B. Kim, L. Li, and A. Edmonds, "Analytical Solutions of LateralTorsional Buckling of Castellated Beams, International Journal of Structural Stability and Dynamics," vol. 16, no. 8, pp. 1-16, 2016

[18]. D Sonck, and J. Belis, "Lateral-Torsional Buckling Resistance of Castellated Beams, Journal of Constructional Steel Research, vol. 105, pp. 119-128, 2016.

[19]. S. Kwani, P. K. Wijaya, "Lateral torsional buckling of castellated beams analyzed using the collapse analysis," Procardia Engineering, vol. 171, pp. 813-820, 2017.

[20]. A. Mohebkah, "Lateral buckling resistance of inelastic I-beams under off-shear center loading," Thin-Walled Structures, vol. 49, pp. 431-436, 2011.

[21]. ANSYS User's Manual, "ANSYS Mechanical APDL Technology Demonstration Guide", Release 18.1, Canonsburg, USA: ANSYS Inc, 2017

Sahar S Elaiwi has completed BSc in Civil Engineering at University of Technology and MS degrees in Structures on Faculty of Civil Engineering, Baghdad University; in 2015 she started her Ph.D. research in Structural Engineering field (Analysis and Design of Castellated Beams) at the University of Plymouth, UK.

She was the engineer at the Ministry of Science and Technology and the Ministry of Higher Education and Scientific Research in Iraq.

\section{Boksun Kim}

\section{Long-Yuan Li}




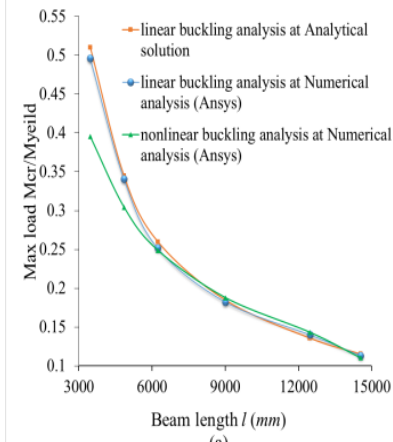

(a)

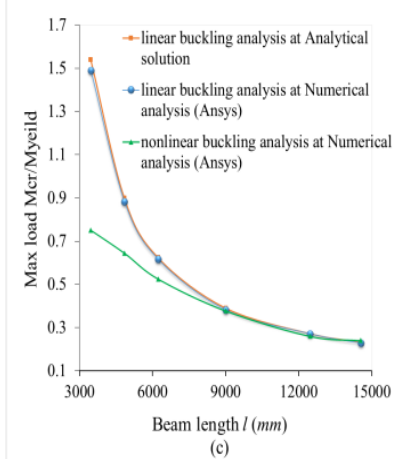

(c)
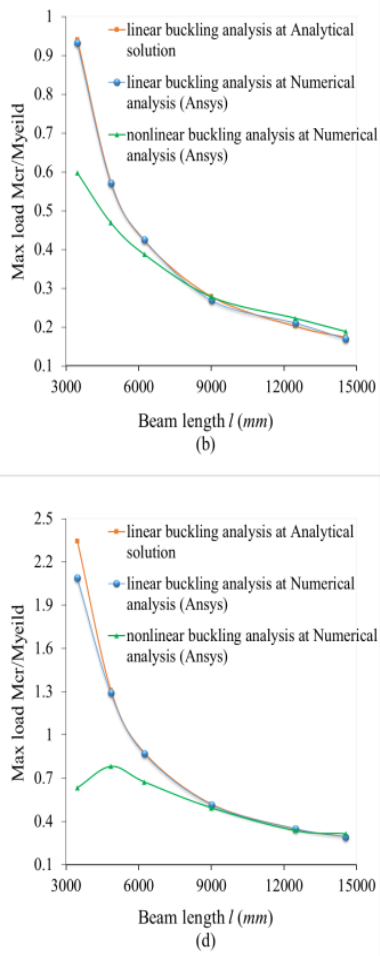

Figure 2. Comparison of critical moments $\left(\mathrm{M}_{\mathrm{cr}} / \mathrm{M}_{\text {yield }}\right)$ of simply supported castellated beam subjected to a uniformly distributed load for various length beams with different flange widths (a) $b f=100 \mathrm{~mm}$, (b) $b f=150 \mathrm{~mm}$, (c) $b f=200 \mathrm{~mm}$, and (d) $b f=250 \mathrm{~mm},\left(h_{w}=300 \mathrm{~mm}\right.$, $t f=10 \mathrm{~mm}, t_{w}=8 \mathrm{~mm}$ and $\left.a=100 \mathrm{~mm}\right)$
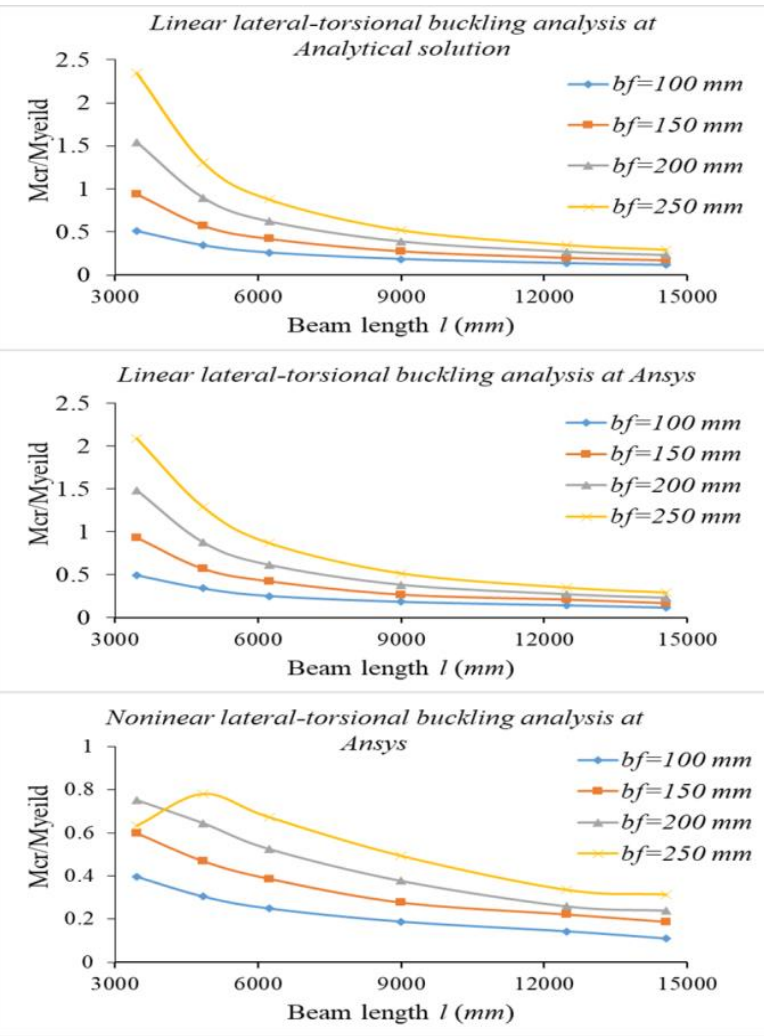

Figure 3. Comparison of critical moments $\left(\mathrm{M}_{\mathrm{cr}} / \mathrm{M}_{\text {yield }}\right)$ of simply supported castellated beam subjected to a uniformly distributed load for various length beams with different flange widths, $\left(h_{w}=300 \mathrm{~mm}\right.$ $t f=10 \mathrm{~mm}, t_{w}=8 \mathrm{~mm}$ and $\left.a=100 \mathrm{~mm}\right)$

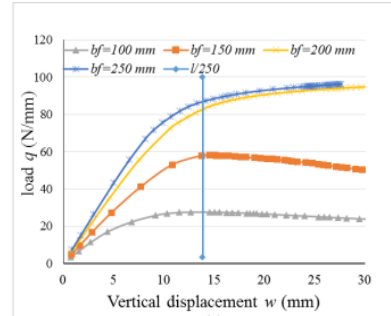

(a)
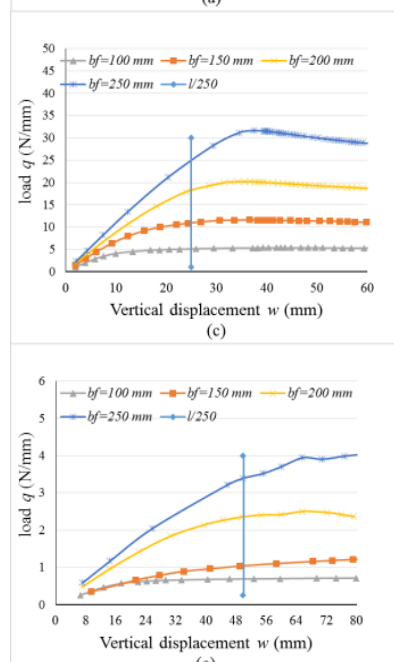

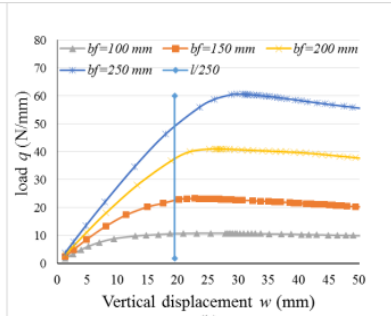

(b)
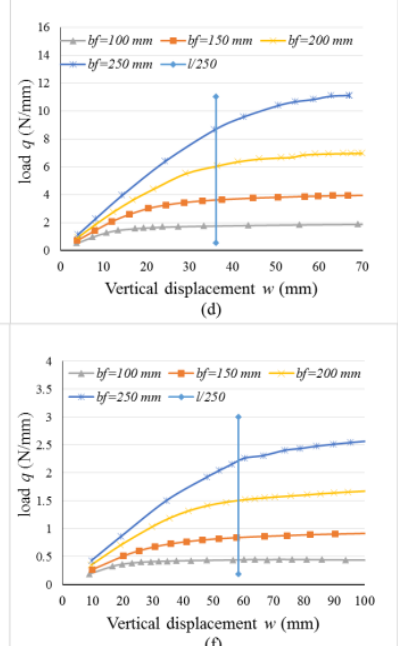

Figure 4. Comparison of the load-deflection curves of simply supported castellated beams subjected to uniformly distributed load, obtained from nonlinear 3D finite element analysis and deflection limit (l/250) for different beam lengths (a) $l=3.464 \mathrm{~m}$, (b) $l=4.849 \mathrm{~m}$, (c) $l=6.235 \mathrm{~m}$, (d) $l=9.006 \mathrm{~m}$, (e) $l=12.470 \mathrm{~m}$ and (f) $l=14.549 \mathrm{~m}$ with various flange widths 


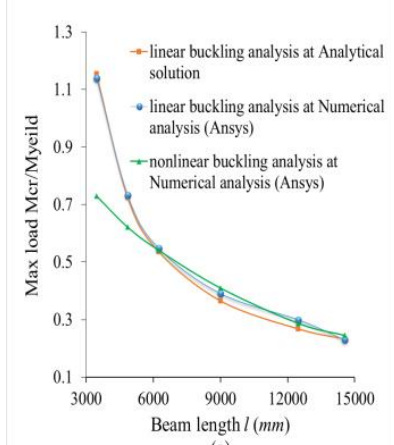

(a)

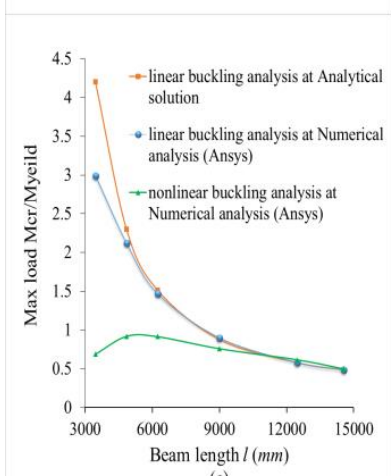

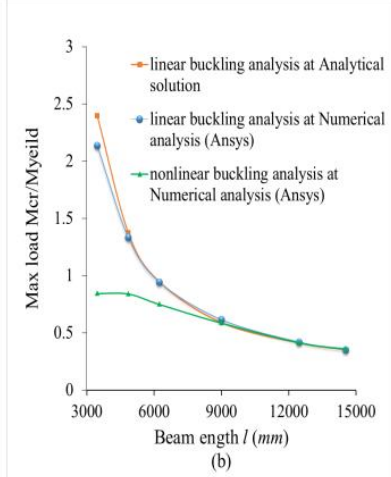

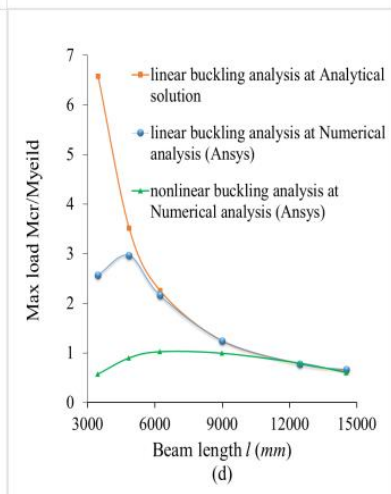

Figure 5. Comparison of critical moments $\left(\mathrm{M}_{\mathrm{cr}} / \mathrm{M}_{\text {yield }}\right)$ of simplyfixed castellated beam subjected to a uniformly distributed load for various length beams with different flange widths (a) $b f=100 \mathrm{~mm}$ (b) $b f=150 \mathrm{~mm}$, (c) $b f=200 \mathrm{~mm}$, and (d) $b f=250 \mathrm{~mm},\left(h_{w}=300 \mathrm{~mm}\right.$, $t f=10 \mathrm{~mm}, t_{w}=8 \mathrm{~mm}$ and $a=100 \mathrm{~mm}$ )

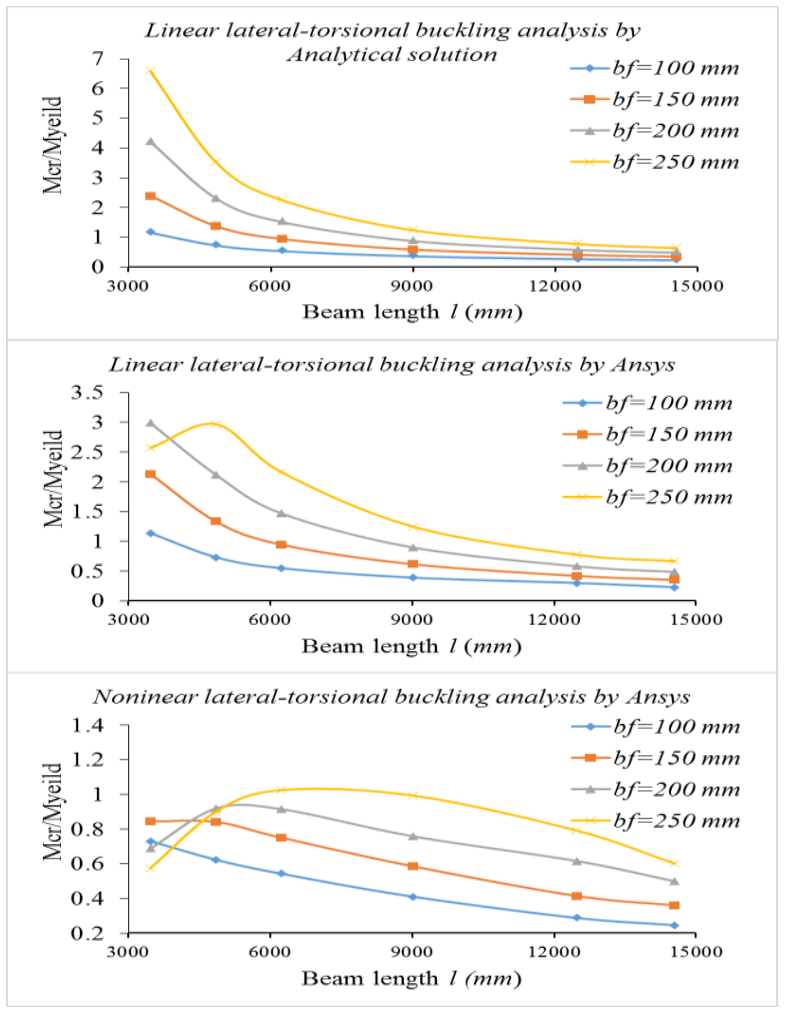

Figure 6. Comparison of critical moments $\left(\mathrm{M}_{\mathrm{cr}} / \mathrm{M}_{\mathrm{yield}}\right)$ of simplyfixed castellated beam subjected to uniformly distributed load for various length beams with different flange widths, $h_{w}=300 \mathrm{~mm}$, $t f=10 \mathrm{~mm}, t_{w}=8 \mathrm{~mm}$ and $a=100 \mathrm{~mm}$

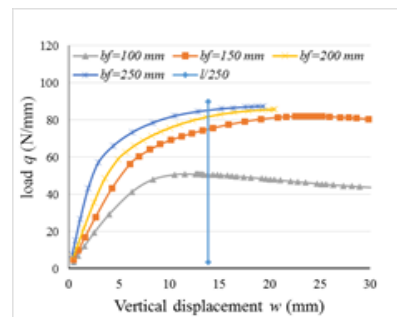

(a)
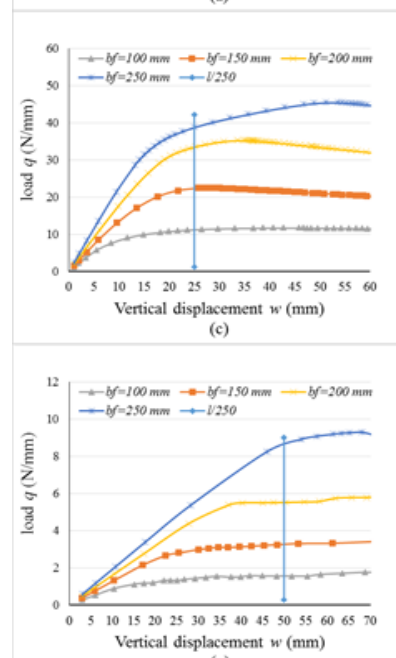

(e)
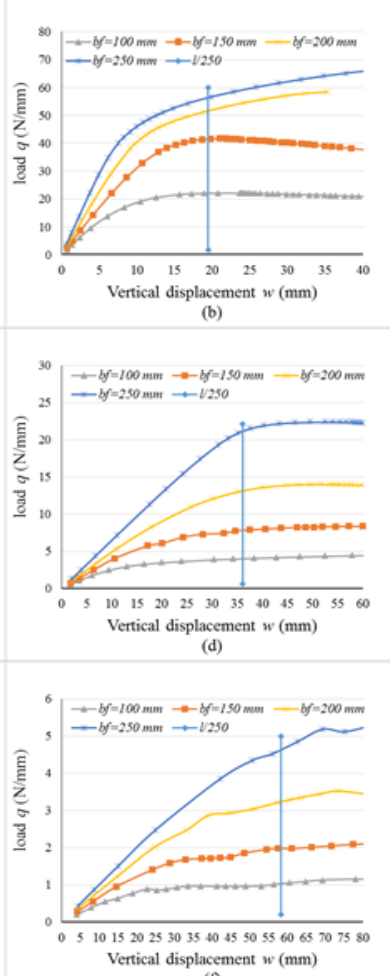

(f)
Figure 7. Comparison of the load-deflection curves of simply-fixed castellated beams subjected to uniformly distributed load, obtained from nonlinear 3D finite element analysis and deflection limit (l/250) for different beam lengths (a) $l=3.464 \mathrm{~m}$, (b) $l=4.849 \mathrm{~m}$, (c) $l=6.235 \mathrm{~m}$, (d) $l=9.006 \mathrm{~m}$, (e) $l=12.470 \mathrm{~m}$ and (f) $l=14.549 \mathrm{~m}$ with various flange widths 


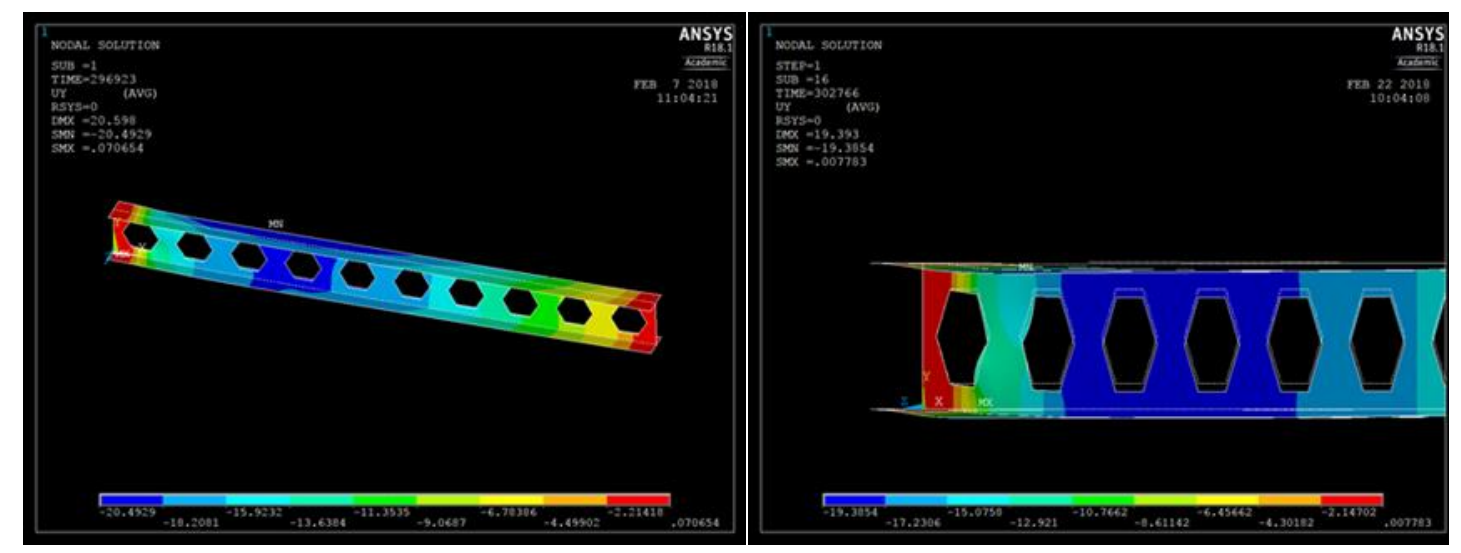

Figure 8. Combined failure modes of pinned-fixed castellated beams subjected to a uniformly distributed load ( $l=3.464 \mathrm{~m})$ with two flange widths (a) and (b) obtained from the nonlinear lateral-torsional buckling 3D finite element analysis using ANSYS software $\left(h_{w}=300 \mathrm{~mm}, t f=10 \mathrm{~mm}, t_{w}=8 \mathrm{~mm}\right.$ and $a=100 \mathrm{~mm})$ 